\title{
AJARAN CATUR ASRAMA PERSEPEKTIF KONSEPSI HIDUP UNTUK MENCAPAI TUJUAN HIDUP
}

\author{
Oleh : I Nyoman Subrata
}

\begin{abstract}
Hindus should be proud because Hinduism has a clear concept of the levels of human life arranged systematically called dormitory chess, namely: four levels of human life based on spiritual guidance that is processed to achieve the goals of human life which is called catur purusaartha based on spiritual order, time, age and nature of human behavior. Four Dormitory or stages in life, namely: Brahmacari Dormitory, namely: the stage of learning or the period of demanding science, Grahasta Dormitory, namely: holdpan household, Wanaprastha Dormitory, namely: stages for asceticism, and Bhisuka Dormitory, namely: life of denial. Each division of Dormitory Chess has its own stages. These stages help human evolution. And Chess Boarding places humanity on perfection by still - each stage. The implementation of Dormitory Chess governs human life from beginning to end
\end{abstract}

Keywords: Dormitory Chess To Achieve Life Goals

\section{Pendahuluan}

Tujuanhidupmanusiaberdasarkan ajaranya agama Hindu adalah "moksartham jagadhita ya caiti dharmah". Atau mencapai "jagathita dan moksa" "jagadhita berati kesejahteran jasmani dan moksa berati ketentraman batin atau kehidupan abadi dengan menunggalnya atman dengan brahman. Dengan demikian tujuan hidup manusia dapat diartikan sebagai usahan untuk mencapai kesejahteran jasmani, ketentraman batin dan kehidupan abadi dengan menunggalnya roh dengan Ida Sang Hyang Widhi. Jadi moksartham jagathita ya ca iti dharmah yaitu menjadi ajaran tujuan hidup manusia. Dan catur asrama merupakan jenjang kehidupan seseorang untuk bermasyarakat. disamping itu dalam menjalankan kehidupan ada tahap yang tingkat / jenjang kehidupan ini dihubungkan dengan umur, tingkat ilmu pengetahuna suci, tingkat spiritual atau rohani, sifat dan perilaku atau moralitas seseorang semua tingkat atau jenjang kehidupan yang dipengaruhi oleh proses perkembanganya sebagai manusia sejak lahir sehingga menjadi sebutan orang tua dengan tingkatan moral dan spiritual yang semakin tinggi dan matang, dalam 
kita suci Bhagawadgita menyebutkan

Niyatam kuru karma tvam

Karma jyayo hy akarmanah

Sarra yatrapi ca re

Na prasiddyed akarmanah

\section{Artinya}

Lakukanlah pekerjaan yang di berikan padamu, karana melakukan perbuatan itu lebih baik sifatnya dari pada tidak melakukan apa -apa, sebagaian juga utk memelihara badanmu, tidak akan mungkin jika engkau tidak kerja

(Bhagawagita III.8.42)

Agama Hindu Memiliki kerangka dasar yang dapat dipergunakan oleh umat sebagai landasan untu memahami, mendalami, dan mengamalkan ajaran ajaran dalam kehidupan sehari-hari. Kerangka dasar agama Hindu yaitu : tatwa/filsafat,susila/etika, dan upacara/ritual. Ketiga unsur kerangka dasar itu merupakan satu kesatuan yang utuh dan tidak terpisahkan. umat Hindu memiliki kewajiban menjadikan kerangka dasar sebagai pedoman. Dengan demikina umat dapat mewujudkan hidup dan kehidupan ini menjadi sejahteran dan bahagia dan dalam pelaksanaannya manusia hendaknya selalu mengupayakan perilaku yang baik dengan sesame umat. Memerlakukan orang lain dengan baik sesungguhnya adalah sama dengan memperlakukan diri sendiri (tatwamasi). Perilaku seperti ini memang patut di upayakan dan dilestarikan dalam setiap tindakkan kita sebagai manusia. Setiap manusia hendaknya selalu berpikir dan bersikap professional menurut guna dan karm. Inilah cermin dari sesosok orang yang telah mengamalkan ajaran catur asrama.
Catur Asrama terdiri atas dua kata yakni “ Catur", yang berarti empat dan "Asrama", berarti tahapan atau jenjang. Jadi Catur Asrama artinya empat jenjang kehidupan yang harus dijalani untuk mencapai moksa. Atau catur asrama dapat pula diartikan sebagai empat lapangan atau tingkatan hidup manusia atas dasar keharmonisan hidup dimana pada tiaptiap tingkat kehidupan manusia diwarnai oleh adanya ciri- ciri tugas kewajiban yang berbeda antara satu masa (asrama) dengan masa lainnya, tetapi merupakan kesatuan yang tak dapat dipisahkan Catur asrama terdiri dari 1. Brahmacari Asrama 2. Grahasta Asrama 3.Wanaprasta Asram 4. Bhisuka Menurut ajaran agama Hndu, dalam brahmacari asrama, seseorang dilarang mengumba hawa nafsu sex. Adapun hubungan antara perilaku seksual dan brahmacari Asrama sebagai berikut

1. Sukla brahmacari asalah : Orang yang tidak kawin semasa hidupnya, bukan karena tidak mampu,melainkan karena mereka sudah berkeinginan untuk nyukla brahmacari sampai akhir hayatnya.

2. Sewala brahmacari adalah : Orang yang menikah sekali dalam masa hidupnya

3. Kresna brahmacari adalah : Pemberian ijin untuk menikah maksimal 4 kali karena suatu alasan yang tidak memungkinkan diberikan oleh sang istri, seperti isang istri tidak dapat menghasilkan keturunan, sang istri sakit-sakitan, dan bila istri sebelumnya memberikan ijin. Dalam Sebuah rumah tangga harus mendapatkan artha yang berlandaskan dhrma dan dipergunakan dengan cara yang pantas. Ia harus memberikan $1 / 10$ bagian dari penghasilannya untuk amal. Beberapa 
kewajiban yang harus dilaksanakan dalam berumah tangga yaitu :

1). Melanjutkan keturunan.

2). Membina rumah tangga.

3). Bermasyarakat.

4). Melaksanakan upacara panca yadnya sesuai dengan ajaran agama Hindu :

a. Dewa Yadnya : persembahan kepada Ida Sang Hyang Widhi Wasa beserta manifestasinya

b. Rsi Yadnya :persembahan pada para rsi, maupun guru

c. Manusa Yadnya : persembahan untuk kesucian lahir batin pada manusia

d. Pitra Yadnya : persembahan pada para leluhur dan Bhetara-bhetari

e. Bhuta Yadnya :persembahan kepada para bhuta.

Dalam masa ini kewajiban kepada keluarga sudah berkurang, melainkan ia mencari dan mendalami arti hidup yang sebenarnya, aspirasi untuk memperoleh kelepasan/ moksa dipraktekkannya dalam kehidupan sehari- hari. Adapun ciri-ciri orang yang telah dapat masuki tahap wanapratha ini adalah: usia yang sudah lanjut, mempunyai banyak pengalaman hidup, mampu mengatasi gelombang pahit getirnya kehidupan, serta mempunyai kebijaksanan yang dilandasi oleh ajaran agama dan ilmu pengetahuan. Telah memiliki keturunan atau generasi lanjutan yang sudah mapan dan mampu hidup mandiri.serta tidak bergantung lagi pada orang tua baik dibidang ekonomi maupun yang lainnya. Sannyasin adalah seoang lakilaki idaman. Ia telah mecapai kesempurnaan dan kebebasan. adalah Brahman sendiri. seoarang jiwanmukta atau seorang bijak yang bebas. Mulialah tokoh pujaan seperti itu yang merupakan Tuhan yang hidup di dunia.

\section{Inplementasi ajaran catur asrama dalam kehidupan}

Kemajuan yang besar dari kehidupan yang modern.Kedamaian dan aturan akan berlaku dalam masyarakat, dan suatu kehidupan yang murni sederhana serta focus pada mengejar ilmu pengetahuan dan wujud Inplementasikan ajaran catur asrama antara lain yaitu :

1. Kepala rumah tangga seharusnya menjalani kehidupan sebuah grhasta yang ideal, ia seharusnya melaksanakan pengendalian diri, welas asih, toleransi, tidak merugikan, berlaku jujur,dan kewajaran dalam segala hal. Selain itu, dengan berbekal ilmu dan keterampilan yang memadai yang didapat pada masa brahmacari, seseorang diharapkan mendapat profesi menjanjikan sesuai dengan keahliannya atau bahkan mampu menciptakan lapangan pekerjaan sendiri. Melalui media itu umat dapat mencari artha dan kama yang didasarkan atas dharma

2. Pada saat menjalankan kehidupan wanaprasta, umat sesungguhnya dituntun untuk mengasingkan diri dari hal-hal yang berbau keduniawian. Dulu, menjalankan kehidupan wanaprasta umat pergi ke hutan untuk menyepikan diri. Tetapi dalam konteks sekarang, "hutan belantara" itu berada di tengah-tengah kita. Agar umat mampu menghindari diri dari kobaran api hawa nafsu, yang memang memerlukan pengendalian diri 
3. Pada tahapan bhiksuka atau sanyasin, umat sangat baik mendalami hal-hal yang bernuasa spiritual untuk mendekatkan diri dengan Sang Pencipta, dan diharapkan umat sudah harus mampu mengendalikan diri dari hawa nafsu dan keinginan duniawi dan dapat menjauhkan diri dari sifat dan musuh yang ada dalam diri seperti sad ripu, sapta timira, sad atatayi, tri mala serta yang sejenisnya

\section{Pembahasan}

\section{Ajaran Catur Astrama sebagai konsepsi hidup Dalam kehidupan}

Untuk mewujudkan cita - cita Hindu Dharma mencapai Jagathita dan Moksha, maka setiap umat Hindu diajarkan untuk mencapai empat tujuan hidup. Empat tujuan hidup disebut dengna Catur Astrama yaitu : Dharma,Artha,Kama, dan Moksa.Empat tujuan hidup ini hanya dapat dicapai melalui tahapan - tahapan hidup sesuai dengan pertumbuhan manusia itu sendiri. Tahapan - tahapan itu di sebut dengan catur astrama. Catur astrama ini adalah konsepsi dasar untuk mencapai Empat tujuan hidup itu. Sebagai konsepsi hidup Catru Astram juga menjadi landasan konsepsi penerangan Hindu Dharma. Karena penerangan Hindu Dharma bertujuan untuk menwujudkan tujuan hidup manusia.

Catur Asrama berasal dari kata catur yang artinya empat dan astrama yang artinya "usahan sesorang" . yang di maksud dengan usahan seseorang dalam pengertian Catur Astrama adalah usahan yng mutlak harus dilakukan oleh seseorang pada tiap - tiap asrama. Bentuk dan jenis usahan hidup yang harus di lakukan pada masing - masing astrama sangat berbeda -beda sesuai dengan unsur Catur Purusaartha yang ingin di capai setiap astrama. Tiap - tipa Catur Purusaartha wajib di wujudkan tiap - tiap astrama. Karena itu penerapan Hindu Dharma harus menunjang terwujudnya tiap -tipa unsur dari Catur Purusaartha pada tahapan - tahapan Catur Astrama itu. Catur Asrtama itu terdiri dari :

\section{A. Brahmacari Asrama}

Brahmacari Astrama yaitu waktu masa kehidupan berguru untuk mendapatkan ilmu pengetahuna weda.Weda mengajarkan pengetahuan untuk memperoleh kebahagian, materal (jagadhita) dan juga mengajarkan tentang tujuan hidup kerohanian (moksa). Dalam masa kehidupan brahmacari ini yang paling di utamakan atau yang di prioritaskan adalah Dharma,Artha,Kama, dan Moksa. Masa kehidupan brahmacari diutamakan untuk mengetahui kewajiban,kebenaran,dan kewajiban yang seluruh itu di sebutdharm. Tatwa dyatmika adalah ilmu pengetahuan tentang rahasia spiritual untuk meningkatakan kedewasan rohani dalam mengahadapi perjalanan hidup. Sedangkan Guru Widya adalah ilmu pengetahuan yang dapat di pakai untuk memperoleh berbagai ketrampilan untuk memdapat pekerjaan dalam memelihara dan meningktkan utu hidup.Tatwa Adyatmika adalah berfungsi untuk mengembangkan sifat sifat baik untuk membangun watak dan karate yang luhur. Sedangkan Guna Widya adalah ilmu pengetahuan yang dapat dipakai untuk memperoleh berbagai ketrampilan untuk memdapat pekerjaan dalam memelihara dan meningkatan mutu hidup ini. Tatwa adyatmika 
adalah berfungsi untuk mengembangkan sifat - sifat baik untuk membangun watak dan karate yang luhur.sedangkan Guna Widya berfungsi untuk mengembangkan bakat bakat pembawaan untuk menjadi ketrampilan yang profisional. Orang yang profisional serta memiliki watak yang luhur merupakan sumber daya manusia yang di harapkan oleh zaman yang semakin maju.

Dalam naskah bahasa Jawa Kuno yang bernama Agastia Parwa kita memdapat keterangan tentang Brahmacari yang lebih lengkap sebagai berikut :

Brahmacari ngarannya sang sedeng mangabyasa sanghyang sastra, muang sang wruh ring tingkahing sanghyang aksara samangkana kramanya sang brahmacari ngaranya

Kunang sang sinangguh brahmacari ring loka ikang tang sanggraheng wisaya istryadi, yeka brahmacari ring loka. Kunang ikang brahmacari waneh sinangguh brahmacari caranam, paraning atmapradesa sang kesepania, sang yogiswara sira brahmacari ring sastrantara ring sastrajna

\section{Artinya}

Brahmacari namanya orang sedang mempelajari ilmu pengetahuan (sastra) dan yang mengetahui prihal ilmu huruf (aksara), orang yang demikian pekerjaannya bernama brahmacari.

Adapun yang dianggap brahmacari di dalam masyarakat adalah orang yang tidak terikat nafsu keduniawian, tidak beristri. Sedangkan brahmacari caranam artinya menuntut ilmu pengetahuan kerohanian (Atmapradesa). Sang Yogiswara, beliau brahmacari di dalam berbagai ilmu (sastrantara), dan di dalam kebijaksanaan (Sastrajna).

Jadi berdasarkan isi Agastia Parwa ini, yang dimaksud brahmacari amat luat pengertianya, yang dapat dirinci sebagai berikut :

1. Orang yang mempelajari ilmu pengetahuan dan ilmu tentang hidup

2. Orang yang terlepas darinafsu keduniawian seperti tidak beristri disebut brahmacari ring loka

3. Orang yang menuntut ilmu pengetahuan kerohaniwan di sebut dengan nama Brahmacari Caranam

4. Sang Yogiswara orang yang ahli dalam berbagai ilmu pengetahuan (sastrantara) dan ilmu pengetahuan kebijaksanaan (sastrajna) disebut brahmacari

Dalam kita Suci Atharwaweda XI.5.1 sebagai berikut :

Brahmacaryena taf asa Raja rastram vi raksati Acarya brahmacaryena Brahmacarinam icchate

\section{Artinya}

Seorang raja, dengan sarana menjalankan berahmacari, bias melindungi bangsanya. Seorang pendidik (guru pembinbing) yang sedang menjalankan brahmacari sendiri berkeinginan mengajar para siswa yang saleh

Brahmacari merupakan tingkatkan hidup yang pertama yang harus di lalui oleh manusia dalam perjalanan hidupnya. Sejak lahir kedunia 
manusia sudah mulai belajar tentang apa yang boleh dilakukan dan apa yang tidak boleh di lakukan, dipikirkan dan dilakukan semakin bertambah umur seorang semakin banyak yang harus di pelajari.

\section{Dalam perjelasan sloka pertama dari naskah slokantara disebut ada tiga macam Brahmacari Asrama yaitu :}

1. Sukla Brahmacari Asrama : orang yang tidak kawin seumur hidupnya bukan karana cacat badan seperti : wangdu, bahkan tidak pernah membicarakan tentang perkawinan sampai di hari tuanya

2. Sewala Brahmacari Asrama : orang yang kawin hanya sekali saja meskipun tinggal mati oleh istrinya

3. Krsna Brahmacari Asrama : orang yang kawin lebih dari sekali dan paling banyak empat kali

Menurut Prof. Dr. Y. Gonda dalam bukunya Sanskrit In Indonesia, membagi Brahmacari Asrama menjadi empat : Sukala Brahmacari Asrama, Trsna Brahmacari Asrama, Sewala Brahmacari Asrama, dan Grhasta Brahmacari Asrama.

Dalam lontar Wrtisesana, pembagian Brahmacari Asrama sama dengan Slokantara Cuma sedikit ada perbedaan pengertian mengenai Sewala Brahmacari Asrama dan Trsna Brahmacari Asrama . Dalam lontar Wrtisesasna yang di maksud dengan Sewala Brahmacari Asrama adalah tidak kawin selama menuntut ilmu. Akan tetapi setalah masa berumah tangga tiba, maka ia kawin untuk memdapatkan keturunan dan juga tahu tentang puja - puja sanggama, tentang waktu dan tempat untuk itu. Dan mengetahui pula siapa - siapa yang patut di kawini untuk memdapat keturuan yang baik. Dari penjelasan naskah tersebut diatas, meskipun ada sedikit perbedaan penjelasan, namun hakekat Brahmacari Asrama adalah suatu usahan untuk memdapat ilmu pengetahuan suci dalam melanjutkan hidup termasuk dalam perkawinan. Ini berati sungguh sulit mendapatkan kebahagiaan hidup berumah tangga tanpa di topang oleh ilmu pengetahuan yang memadai.

\section{B. Grhasta Asrama}

Grhasta Brahmacari hidup berumah tangga, bersuami istri. Pada masa kehidupan Grahasta tujua hidup diproritaskan untuk mendapatkan artha dan memenuhi kama. Oleh karana itu suatu rumah tangga belum dapat di dirikan kalau belum siap dengan sumber artha berupa pekerjaan yang tetap yang memberi hasil yang memadai untuk memjalankan rumah tangga. Demikian dengan kama yang mendorong hidup seperti : nafsu haus, lapar dan seks. Tiga dorong hidup itu harus terpenuhi dengan berlandasan dharma. Kama adalah salah satu media untuk memdapatkan kebahagiaan dan jangan sampai kama itu memperalat manusia (sang diri). Sang diri harus mampu membatasi kama. Manusia tanpa kama tidak akan menikmati kehidupan yang sejati dari hidup di dunia ini. Akan tetapi kalau kama tanpa batas dan tidak kendali, maka keindahan dunia ini akan berbalik menjadi sumber kehancuran . demikianlah hidup dalam Grhasta Astrama harus berlandasan dharma. Grhasta Asrama tanpa berlandasan dharma akan mengakibatkan artha dan kama yang merupakan prioritas utama dalam Grhasta 
Asrama menjadi sumber kehancuran Grhasta Asrama itu sendiri Di dalam Agastia Parwa di jelaskan tentang Grahasta Asrama sebagai berikut :

Grhasta ta sira mastri pwa sira, manak madrewya

Hulu, ityewawadi, mangunake kayekadharma yat hasakti

\section{Artinya}

Grhasta -lah beliau, mempunyai anak, memiliki abdi, memupuk kebajikan yang berhubungan dengan pembinaan diri pribadi, (kayikadharma) dengan kekuatan yang kehidupan

\section{Wanaprastha Asrama}

Wanaprastha Asrama berasal dari kata bahasa sansekerta. Terdiri terdiri dari kata wana yang artinya pohon katu atau semak belukar dan prastha yang artinya berjalan/ berdoa dengan baik. Wanaprastha yang di maksudkan berada dalam hutam, mengasihkan diri dalam arti menjauhi dunia ramai secara peelahan - lahan untuk melepaskan diri dari ikatan duniawi wanaprastha adalah jenjang kehidupan untuk mencari ketenangan batin, dan mulai melepaskan diri dari kerikatan terhadap kemewahan duniawi

Masa ini adalah masa peralihan antara kehidupan yang masih bersifat dunia yang penuh tanggung jawab dan keterikatan pada keluarga secara berlahan hidup menuju sebuah pengasingan diri terhadap ikatan tersebut hingga yang tersisa adalah hubungan antara diri sendiri dengan tuhan dan tidak ada lagi hubungan yang lain yang dikenal sebagai Sanyyasin Asrama atau Bhisuka Asrama. Wanaprastha Asrama tidak tidaklah diartikan sebagai meninggalkan rumah lalu pergi menyepi kehutan untuk bertapa, tetapi Wanaprastha dimaknai sebagai hidup yang hening dan suci. Sedikit demi sedikit melepaskan diri dari ikatan keduniawian dan menguatkan pengendalian diri berdasarkan Ajaran Agama Hindu yang di peroleh pada masa Brahmacari Asrama kini dilaksanakan pada kehidupan sehari hari - hari dan lebih mengarah pada bidang spiritual.

Orang yang melaksanakan wanaprastha disebut wanaprasthin hendaknya selalu menjaga kesucian dan kesehatan jasmani/ rohani, banyak melakukan pekerjaan mulia, bijaksana, bersahabat, berbicara manis dan menyenangkan, melakukan sedhana, melaksanakan latian kerohanian (yoga) melakukan berbagai "vrata" atau pengekang diri dari seks, belajar dan bergaul pada orang suci (sulinggih), sering medharma yatra. Adapun manfaat menjalankan hidup Wanaprastha adalah

a. Untuk mencapai ketengan rohani

b. Memanfaatkan rasa kehidupan di dunia untuk mengabdi dan berbuat amal

kebijkan kepada masyarakat umum

c. Melepaskan segala kerikatan terhadap duniawi

Masa yang paling baik dalam menjalankan wanaprastha adalah setelah berusia kurang lebih 60 tahun keatas

\section{Bhisuka Asrama}

Kata bhisuka berasal dari kata bhiksu sebutan untuk pendeta Bhuda. Bhiksu berati 
meminta-minta. Bhisuka adalah tingkat kehidupan yang lepas dari ikatan duniawian dan hanya mengabdikan diri kepada Hyang Widhi dengan jalan menyebarkan ajaran - ajaran kesusilaan. Bagi yang yang telah menjalankan hidup bhisuka telah mampu menunduhkan musuh - musuh yang ada pada dirinya, seperti : Sad Ripu, Sapta Timire, Sad Atatayi, dan Tri Mala

Adapun bagianya dari Sad Ripu adalah enam musuh yang ada dalam diri manusia yaitu : a. Kama yautu : hawa nafsu, b.Lobha yaitu : tamak, c.Krodha yaitu : kemarahan, d.Moha yaitu : kebingunan, e.Mada yaitu : kemabukkan, f. Matsarya yaitu : iri hati.

Adapun bagianya dari Sapta Timira tujuh hal yang menyebabkan pikiran manusia menjadi gelap yaitu : a. Surupa yaitu : kecantikan / krbahahian, b. Dana yaru : kekayaan, c. Guna yaitu : kepandaian, d. Kulina yaitu : keturunan, e. Yowana yaitu : masa muda, f. Sura yaitu : minuman keras, g. Kasuran yaitu : keberanian

Adapun bagianya dari Sad Atatayi adalah : enam macam pembunuh kejam yaitu :a. Agnida yaitu : membakar milik orang lain, b. Wisada yaitu : meracun, c. Atharwa yaitu : melakukan ilmu hitam, d. Sastraghna yaitu : mengamuk, e. Dratikrama yaitu : memperkosa, f. Raja pisuna yaitu memfinah

Adapun bagianya dari Tri Mala adalah tiga perbuatan kotor yaitu : a. Kasmala yaitu : perbuatan hina dan kotor, b. Mada yaitu : perkataan, pembicaraan yang hina dan kotor, c. Moha yaitu : pikiran perasaan yang curang dan angkuh

\section{Dalam ajaran Agastia Parwa di jelaskan tentang wanaprastha dan Bhisuka sebagai berikut}

Wanaprastha ta sire, mur saking grama mwang, mungwing suci desa, makadi mukir, magawe patapan, sthananira gumawayaken pancakarma mwangi wisaya mwang mangdesanaken dharma, huwus pwa sira wanaprastha, bhiksuka ta sira, mur saking patapan ira, nisparigraha,tan pangku patapan, tan pangaku sisya,tan pangku pangruh, padaya tininggalaken ira

\section{Artinya}

Wanaprastha-lah beliau. Pergi dari desa dan menetap ditempat yang bersih suci terutama di gunung. Mendirikan bertapaan sebagai tempatnya melakukan panca karma dan mengurangi nafsu keduniawian serta mengajarkan ajaran kerohanian. Setelah beliau mengajarkan ajaran kerohanian. Setelah beliau melakukan wanaprastha, bhiksuka-lah beliau, pergi dari pertapaanya. Tiada terikat,tidak mengaku memiliki pertapaan,tidak merasa punya murid, tidak merasa berpengetahuan, semua itu di tinggalkan oleh beliau

Demikian Catur Asrma merupakn empat tingkat hidup yang bersifat formal dan tidak kaku dalam penerapanya dalam hidupan sehari -hari. Dalam hal ini hubungan antara Catur purusaartha atau Catur Warga adalah empat tujuan hidup yang berjalin erat dan saling tunjang menunjang satu dengan yang lainnya tak dapat dipisahkan satu dengan yang lainnya. Dharma adalah dasar untuk mendapat artha,kama dan moksa. Tetapi sebaliknya 
tanpa artha,kama dan moksa. Dharma-pun tidak dapat di jalankan dengan sempurna. Tidak ada swardarma, (kewajiban) atau kebenaran yang dapat dilaksanakan dengan sempurna tanpa arta,dan kama. Misalnya : menuntut ilmu ataupun berdana punia adalah perbuatan dharama tetapi kesemua itu baru dapat dilaksanakan kalau ada arta dan kama. (keinginan atau semangat) demikian pula moksa beraal dari bahasa sankeserta dari urat kata. Much artinya bebas tanpa ikatan kebebasan tersebut adalah merupakan kenyataan yang setiap saatdi perjuangkan oleh manusia. Untuk memdapatkan kebebasan yang paling ideal, membutuhkan perjuangan yang sungguh sungguh dan bertahap.

Dalam Grhasta Asrama seorang kepala rumah tangga yang baik tentunya memiliki perencanaan dalam meminpin rumah tangga, itu wajib dilakukan seorang kepala rumah tangga dengan keyakinan dan kesungguhan. Kewajiban Grhasta Asrama merupakn ikatan suci (dharma). Moksa atau kebebasan dari ikatan merupakn kenyataan hidup yang harus di perjuangan secara bertahap, dengan pasti dan penuh keyakinan. Kalau ikatan demi ikatan dalam hidup ini dapat dilepaskan satu demi satu secara bertahap maka kebebasn yang paling ideal berupa moksa akan dapat tercapai. Untuk itu kebebasan suatu kebutuhan nyata bagi manusia untuk diraih secara bertahap sehingga mencapai puncaknya inilah kebebasan yang di sebut dengan moksa.

Dalam Catur Purusaartha atau Catur Warga merupakan tujuan hidup setiap umat Hindu. Maka Catur Arama adalah konsepsi hidup untuk mencapai tujuan hidup. Jadi Catur Purusaartha dan Catur Asrama ini adalah landasan konsepsional dari hubungan sosiologis antara manusia dengan manusia, mendapatkan kesejahteran fisik material (jagadhita) dan sejahteran moral spiritual (moksa)

\section{Penutup}

Untuk mewujudkan cita -cita Hindu Dharma mencapai jagadhita dan moksa, maka setiap umat Hindu dalam Catur Asrama dapat pula diartikan empat tingkatan hidup manusia atas dasar keharmonisan dimana tiap-tiap tingkat kehidupan manusia di warnai oleh adanya ciri ciri tugas dan kewajiban yang berbeda antara satu masa (asrama) dengan masa lainya, tetapi merupakan kesatuan yang tidak dapat di pisahkan

Ciri -ciri orang Brahmacari Asrama yaitu : a.Orang yang sedang mengikuti ilmu pengetahuan, b.Orang terlepas dari nafsu keduniawian,c. Orang yang menuntut ilmu pengetahuan kerohanian di sebut dengan nama brahmacari

Ciri ciri Grahasta Asrama yaitu a. Pada tingkat ini banyak dilakukan kunjungan seperti : dharma yatra,tirta yatra ketempat suci di mana seluruh sisa hidup hanya diserahkan pada sang pencipta untuk mencapai oksa

Ciri- ciri orang Wanaprasta Asrama yaitu :a.Untuk mencapai ketenangan rohani, dan filsafatnya adalah : orang menang tidak pernah mengalahkan dan orang kaya karana tidak pernah miskin, b. Manfaat sisa hidup untuk mengabdi kepada masyarakat. c. Melepaskan segala keterikatan duniawian

Ciri - ciri orang Bhisuka Asrama yaitu : a.Selalu melakukan tingkah laku yang baik dan bijaksana, b. Selalu memancarkan sifat sifat 
yang menyebabkan orang lain bahagia, c. Dapat menunduk musuh - musuhnya seteri : sadripu, kama/nafsu, loba/tamak/rakus, kroda/marah, moha/bingung, mada/mabuk, dan matsyarya/ iri hati. d.Menurut kita suci nitisastra masa wanaprastha umur kurang lebih 50-60 tahun

Dari uraian di atas bahwa ajaran catur asrama dan catur purusaartha sangat berkaitan dan sangat baik jika di gunakan sebagai pedoman dalam melaksanakan kegiatan di masa hidup ini. Ajaran Catur Asrama yakni bramacari, grhasta, wanaprastha dan bhisuka merupakan fase kehidupan dan Catur Purusaarta yakni : dharma,artha,kama dan moksa merupakan tujuan dari kehiduapn ini. Pada masa brahmacari seorang penuntut ilmu gunanya untuk memperoleh pekerjaan (dharma,dan artha) .pada masa grahasta atau berumah tangga seseorang akan mencari kekayaan untuk memenuhi keinginanya (kama) yang berlandasan kebenaran atau dengan cara - cara yang baik (dharma). Pada masa wanaprastha seorang mulai sedikit demi sedikit mengurangi keinginan atau hawa nafsu (kama) dan mulai mencari ketenangan guna mencapai kelepasan (moksa) dan tidak lagi terikat dengan hal - hal yang bersifat keduniawian

\section{DAFTAR PUSTAKA}

Sudharta Tjok.2003. slokantara untaian ajaran etika. Paramita.surabaya.

Wiana ketut. 1997.Cara belajar agama hindu yang baik. Pustaka bali post.Denpasar

Pudja,Gede. 2005. Bhegawadgita, Pancama weda. Paramita Surabaya.
Pendit Nyoman.1993. Aspek - aspek Agama Hindu.pustika manik geni. Jakarta

Triguna yuda.2000. kontribusi hindu terhadap ilmu pengetahuan dan peradaban.Widya dharma.denpasar 